\title{
EHEYTTÄVÄÄ KEMIAN OPETUSTA OPPIAINEIDEN VÄLISENÄ YHTEISTYÖNÄ
}

\author{
Outi Haatainen, Päivi Kousa, Toni Asikainen, Nelly Heiskanen, \\ Anna Sjöblom \& Maija Aksela \\ Kemian opettajankoulutusyksikkö, Kemian laitos, Helsingin yliopisto
}

Kevään 2015 Kemian opetuksen keskeiset alueet II -kurssin opiskelijat perehtyivät eheyttävään kemian opetukseen oppiaineiden välisenä yhteistyönä. Opiskelijat kehittivät opetussisältöön sopivan tuntisuunnitelman, jota he testasivat valitsemassaan yläkoulussa. Eheyttäväksi oppiainekokonaisuudeksi valikoitui kemia ja matematiikka sekä kemia ja englanti. Tukea eheyttävän tuntisuunnitelman sisällön laatimiseen oppilaat saivat yhteistyökoulun opettajalta. Tämä yleisartikkelikokonaisuus sisältää kolme opiskelijan laatimaa artikkelia. Artikkelit perustuvat tuntisuunnitelmiin ja niiden teoreettinen tausta eheyttävään opetukseen sekä tunnilla käsiteltyyn aiheeseen. Suunnitelmissa on otettu huomioon uudistuneet perusopetuksen opetussuunnitelman perusteet (2014) erityisesti eheyttävän opetuksen, kestävän kehityksen ja tieteen luonteen osalta. Valmiit tuntisuunnitelmat löytyvät osoitteesta http://www.luma.fi/materiaalit ja sopivat sellaisenaan tai soveltuvin osin opettajan hyödynnettäviksi.

\section{Omaa pakkausta suunnittelemassa}

\section{Toni Asikainen}

\subsection{Johdanto}

Uusissa opetussuunnitelman perusteissa eheyttävä opetus on yksi opetuksen painopisteistä. Siinä koulutuksen järjestäjä velvoitetaan järjestämään vähintään yksi laajempi kokonaisuus eheyttävästä opetuksesta. (Opetushallitus, 2014) Monialaisen oppimiskokonaisuuden tarkoituksena on valmistaa oppilaita paremmin heidän tuleviin ammatteihinsa, jotka ovat nykypäivänä yhä monialaisempia. Tutkimustulosten perusteella eheyttävällä opetuksella on positiivisia vaikutuksia oppimistuloksiin ja oppilaiden kiinnostukseen oppiaineita kohtaan (Czesniak \& Johnson, 2014). Koska jokainen peruskoulun opettaja tulee törmäämään eheyttävään opetukseen, on siten tärkeää, että opettajilla on valmiuksia sen toteuttamiseen.

Kestävä kehitys on luonnostaan monialainen konteksti (Miller, 2014). Kestävällä kehityksellä tarkoitetaan tapaa, jolla nykyihmiset voivat käyttää resursseja hyväkseen ja säästää niitä riittävästi myös tulevien sukupolvien tarpeisiin. Kestävä kehitys sisältää ympäristöllisiä, taloudellisia ja sosiaalisia näkökulmia (Giddings, Hopwood \& O’Brien, 2002). Siksi se soveltuu hyvin käytettäväksi eheyttävän opetuksen kontekstina koulussa. Kestävän kehityksen käyttö eheyttävän opetuksen kontekstina auttaa oppilaita siirtämään koulusta saatuja tietoja tulevaan työympäristöön (Illeris, 2009). Tämän artikkelin päätavoite on tarjota opettajalle esimerkki sellaisesta eheyttävästä oppitunnista, jonka voi laajentaa suuremmaksi projektiksi. Tavoitteena on lisäksi tarjota materiaalia eheyttävään opetukseen, koska sitä ei ole tutkimusten mukaan tarpeeksi (Czesniak \& Johnson, 2014). Oppitunti on 
suunniteltu eheyttämään kemiaa ja matematiikkaa, mutta siihen voi lisätä myös muita oppiaineita, kuten äidinkieltä, tietotekniikkaa tai yhteiskuntaoppia. Oppitunti on toteutettu 9. luokalla 75 minuutin pituisena.

\subsection{Materiaalit ja kestävä kehitys opetettavana aiheena}

Kestävä kehitys ja materiaalit kuuluvat yläkoulun kemiassa opetettaviin aiheisiin. Opetussuunnitelman mukaisia aihesisältöjä ovat kestävän kehityksen mukaisen ajattelun kehittäminen, tuotteen elinkaari sekä luonnonvarojen kestävä käyttö (Opetushallitus, 2014).

Yläkoulun kemian tunnilla esiteltäviä materiaaleja ovat esimerkiksi muovit, metallit sekä paperi. Öljystä valmistettavat muovit sisältävät pitkäketjuisia polymeereja, jotka koostuvat pienemmistä yksiköistä, monomeereista. Useimmat muovit ovat kevyitä, helposti muokattavia, joustavia ja edullisia. Muovit voidaan jakaa ominaisuuksiensa perusteella kesto- ja kertamuoveihin. Kestomuoveja ovat esimerkiksi muovipussien valmistuksessa käytettävä polyeteeni ja polyeteenitereftalaatti, joka on virvoitusjuomapullojen yleisin valmistusmateriaali. Kestomuovit voidaan kierrättää ja käyttää uudelleen esimerkiksi sulatuksen ja uudelleenmuokkauksen avulla. Kertamuoveja, kuten autojen muoviosissa ja erilaisissa eristelevyissä käytettävää polyuretaania ei voi muokata uudelleen. Ne kertamuovit, joista ei vapaudu myrkyllisiä aineita, kuten klooriyhdisteitä, voidaan hävittää polttamalla. Poltettavaksi sopimattomat muovit viedään kaatopaikalle. (Kangaskorte, Lavonen, Penttilä, Pikkarainen, Saari, Sirviä, Vakkilainen \& Viiri, 2010)

Metallit ovat alkuaineita tai yhdisteitä, joita voidaan hankkia hyötykäyttöön esimerkiksi malmia rikastamalla. Metallit ovat kestäviä, kiiltäviä, helposti työstettäviä sekä hyviä lämmön- ja sähkönjohteita. Opetuksen kannalta keskeisiä metalleja ovat muun muassa rauta, kupari ja nikkeli. Nykyään valtaosa käyttömetallista voidaan kierrättää, mutta suuren kysynnän vuoksi metalleja pitää louhia koko ajan lisää. Maankuoressa ei kuitenkaan ole loputtomiin metalleja ja sen vuoksi niiden kierrätys on kestävän kehityksen kannalta tärkeää. (Kangaskorte et al., 2010)

Paperi koostuu pääasiassa puusta saatavasta selluloosasta. Varsinainen paperi on kokonaan uusiutuvaa ja kierrätyskelpoista materiaalia, mutta sen valmistuksessa käytettävillä valkaisu- ja valmistusaineilla on vaikutuksia ympäristöön. Näitä kemikaaleja ovat muun muassa klooripohjaiset yhdisteet ja vahvat emäkset. Eri paperilaaduista pakkauspaperi lukeutuu vahvimpiin. (Kangaskorte et al., 2010)

Erilaisten materiaalien alkuperän ja ominaisuuksien lisäksi kestävän kehityksen ja tuotteen elinkaaren kannalta on tärkeää miettiä materiaalien käyttöikää, uudelleenkäyttömahdollisuutta ja jätteiden hävittämistä. Kestävä kehitys on luonteeltaan monialaista (Miller, 2014). Näin ollen se soveltuu hyvin eheyttävän opetuksen kontekstiksi. Kestävän kehityksen opetus auttaa oppilaita linkittämään opitun tiedon todelliseen maailmaan (Warner, B. P. \& Elser, M., 2015). Tämä on myös yksi eheyttävän opetuksen tavoitteista sekä yksi tämän artikkelin tavoitteista. Oppilaiden tulisi ymmärtää miten kemian ja matematiikan tietoja sovelletaan oikeassa maailmassa. 


\subsection{Eheyttävä opetus}

Eheyttävällä opetuksella tarkoitetaan opetussuunnitelman (Opetushallitus, 2014) mukaan oppiainerajoja ylittäviä kokonaisuuksia, jotka ovat liitetty arkielämän ilmiöihin tai teemoihin. Eheyttämistä voidaan toteuttaa $\mathrm{mm}$. seuraavilla menetelmillä: rinnastamalla samaa teemaa samanaikaisesti eri oppiaineissa, jaksottamalla samaan teemaan liittyviä sisältöjä erilaisia toiminnallisia aktiviteettejä käyttäen, toteuttamalla eri oppiaineiden välisiä suurempia monialaisia opintokokonaisuuksia tai esiopetuksen kaltaisena kokonaisopetuksena. Eheyttävän opetuksen tavoitteena on saada opetuksen sisällöt lähemmäksi oppilaan arkea ja oppilaat osallistumaan opetuksen suunnitteluun ja toteutukseen. Koulua velvoitetaan myös järjestämään oppilaille yksi suurempi eheyttävä kokonaisuus oppivuoden aikana (Opetushallitus, 2014).

Czesniak ja Johnson (2014) ovat todenneet, että eheyttävällä opetuksella saadaan aikaan parempia oppimistuloksia ja sen avulla voidaan lisätä opiskelijoiden kiinnostusta tiedeopetukseen ja tulevaisuuden ammatteihin. Eheyttävää opetusta saaneet oppilaat ovat Gilbertin (2011) mukaan saaneet parempia oppimistuloksia kuin perinteistä opetusta saaneet verrokkiryhmät. PISA -tulosten mukaan kiinnostus kemian opiskelua kohtaan on Suomessa vähäisempää kuin muissa OECD -maissa (PISA, 2006). Eheyttävällä opetuksella on näin ollen selkeästi perusteltu paikka uusissa opetussuunnitelman perusteissa.

Eheyttävään opetukseen voi sisältyä opettajien mielestä ongelmia. Lurtin ja Pehlivan (2013) mukaan opettajilla ei ole heidän omasta mielestään tarpeeksi valmiuksia ja kokemusta toteuttaa eheyttävää opetusta tehokkaasti luonnontieteiden ja matematiikan välillä. Näiden syiden takia he eivät uskalla käyttää omatoimisesti eheyttävää opetusta omilla tunneillaan. Varsinkin matematiikan opettajat ovat sitä mieltä, että heillä ei ole tarpeeksi tietotaitoa toteuttaa eheyttävää opetusta. Näistä ongelmista huolimatta opettajat pitävät eheyttävää opetusta yleisesti hyvänä lähestymistapana ja suhtautuvat sen vaikutuksiin positiivisesti. Opettajat ovat myös huolissaan siitä, että eheyttävä opetus vie aikaa tärkeiden sisältötietojen opetuksesta. Muita eheyttävän opetuksen toteuttamisen ongelmia ovat materiaalin puute, lisääntyvä opetusmäärän tarve, sekä oppiainejako (Czesniak \& Johnson 2014).

Edellä esitetyistä tutkimustuloksista huomataan, että eheyttävällä opetuksella on käytännön haasteista huolimatta positiivisia vaikutuksia oppimiseen. Myös opettajat suhtautuvat eheyttävän opetuksen vaikutuksiin positiivisesti ja olisivat valmiita tuomaan sitä enemmän ja paremmin esille kouluissa, mutta he tarvitsevat apua käytännön toteutuksiin sekä lisäkoulutusta ja valmiita, käytännöllisiä materiaaleja. Tämän artikkelin yhteydessä oleva tuntisuunnitelma tarjoaa yksinkertaisen mallin toteuttaa eheyttävää opetusta kemian ja matematiikan välillä. 


\subsection{Esimerkkinä oman pakkauksen suunnittelu}

\subsubsection{Tavoitteet}

Tässä artikkelissa esitetyn eheyttävän oppitunnin aiheena oli ympäristöystävällisen pakkauksen suunnittelu kuvitellun yrityksen tarpeisiin. Pakkauksen suunnittelutyö suoritettiin avoimena tehtävänä eheyttävän opetuksen periaatteita noudattaen. Oppilaat saivat itse valita yrityksen, pakkauksen ja siihen käytettävät materiaalit sekä suunnitella pakkauksen ulkoasun. Yhtenä tavoitteena oli saada oppilaat soveltamaan koulussa oppimiaan kemian ja matematiikan tietoja arjesta tuttujen kontekstien avulla. (Illeris, 2009)

Oppilaan tulisi käyttää oppimaansa tietoa erilaisissa, koulusta poikkeavissa ympäristöissä. Tiedonsiirtokykyä tarvitaan viimeistään silloin, kun oppilas siirtyy kouluympäristöstä poikkeavaan työympäristöön. Tätä tiedonsiirtoa voidaan harjoittaa muokkaamalla tavallista opetusympäristöä lähemmäksi työympäristöjä. Tämän työn avulla pyrittiin simuloimaan yrityksen suunnittelijoiden työtä kahta eri oppiainetta, kemiaa ja matematiikkaa yhdistämällä. Oppitunnin toisena tavoitteena oli harjoitella tiedon siirtoa koulussa opituista asioista koulun ulkopuolelle, kuten työelämään. Valitsemalla oppilaiden arjesta tuttuja konteksteja pyrittiin välttämään mahdollisia oppilaan tiedon siirtoon liittyviä ongelmia. (Illeris, 2009)

\subsubsection{Oppitunnin suunnittelu ja toteutus}

Fitzgeraldin ja Tsosien artikkelissa (2012) esitellään muropaketin suunnittelutyö, jonka pohjalta tässä esiteltyä oppituntia on osin kehitelty. Fitzgeraldin ja Tsosie (2012) antoivat oppilaille etukäteen tiedot halutusta pakkauksesta (muropaketti, joka on suorakulmainen särmiö), joten tehtävä on tässä artikkelissa esitettyä pakkaussuunnitelmaa suljetumpi.

Oppituntia varten on hyvä miettiä, mitä asioita haluaa pakkauksen suunnittelussa painottaa. Tämän artikkelin tunnilla painopiste oli enemmän materiaaleissa ja kestävässä kehityksessä kuin matematiikassa. Tunnille saa kuitenkin helposti tuotua matematiikkaa, kuvaamataitoa tai tietotekniikkaa pienten muutosten avulla. Oppituntia suunnitellessa on hyvä huomioida, että oppilaat valmistuvat hyvin eri tahtia. Nopeimmille oppilaille on hyvä suunnitella tekemistä esimerkiksi toisesta integroitavasta oppiaineesta. Omassa tapauksessani olisin voinut esimerkiksi pyytää nopeimpia laskemaan, kuinka paljon kutakin materiaalia heidän pakkaukseensa olisi kulunut. On kuitenkin hyvä muistaa, että lisätyöt saattavat tuntua nopeammista oppilaista epäoikeudenmukaisilta, joten lisätehtävien tulisi olla mielekkäitä. Tätä opettajat joutuvat miettimään myös muilla kuin eheyttävillä oppitunneillaan.

Alkuperäisen suunnitelman pinta-alalaskut jouduttiin toteutuksesta jättämään pois, koska oppilailla kului suunniteltua enemmän aikaa aiheen ja materiaalien valinnassa sekä pakkauksen piirtämisessä. Työhön olisi voinut ottaa mukaan myös tiedonhakua materiaaleista, pakkausten muodoista ja niiden ympäristöystävällisyydestä. Suunnitelmat olisi voitu tehdä tietokoneella, jolloin tietotekniikan oppiminen olisi voitu liittää eheyttävään 
kokonaisuuteen. Saadun opetuskokemuksen perusteella pakkaussuunnitteluun liittyvää oppituntia voisi laajentaa kahden oppitunnin kokonaisuudeksi. Tällöin töistä saisi viimeistellympiä ja mukaan ehtisi ottaa syvemmin myös eheyttäviä osia.

Fitzgeraldin ja Tsosien (2012) laatima muropaketin suunnittelutyö sisältāä hyviä ehdotuksia siitä, miten oppitunnin aihetta voidaan laajentaa kuvaamataidon, yhteiskuntaopin, historian, äidinkielen ja melkein minkä tahansa oppiaineen puolelle. Vastaavasti tässä esiteltyä suunnitelmaa voisi laajentaa suuremmaksi kokonaisuudeksi lisäämällä muita oppiaineita mukaan. Tällöin oppitunnista voisi muokata laaja-alaisen kokonaisuuden, joita peruskoulujen velvoitetaan tekemään vähintään yksi lukuvuodessa.

\subsection{Yhteenveto}

Eheyttävä opetus tulee olemaan läsnä uudessa opetussuunnitelmassa ja sen myötä myös kouluissa. Eheyttävän opetuksen hyödyistä on tutkimustietoa ja opettajatkin ymmärtävän sen hyödyllisyyden, mutta opettajien mielestä heillä ei ole tarpeeksi valmiuksia toteuttaa sitä. Ongelmina on pidetty tietotaidon ja materiaalin puutetta, sekä koulun strukturoitua rakennetta. Tämän artikkelin pohjana toimiva tuntisuunnitelma on yksi esimerkki opettajille, miten eheyttävää opetusta voidaan toteuttaa kemian ja matematiikan osalta. Sitä voi helposti myös laajentaa suuremmaksi kokonaisuudeksi ja ottaa mukaan luonnontieteille vieraampia aineyhdistelmiä.

Kestävä kehitys on uuden opetussuunnitelman osa-alue, joka toimii luonnollisena kontekstina tälle tuntisuunnitelmalle. Eheyttävä opetus kestävän kehityksen kontekstina on yksi yritys vastata oppilaiden tarpeeseen soveltaa tietoa laaja-alaisesti tulevissa ammateissaan. Nykyajan ammatit ovat harvoin enää yhden oppiaineen tiedon varassa ja työntekijöiltä odotetaan laajempien kokonaisuuksien hallintaa. Tämä oppitunti on yksi esimerkki siitä, miten eri oppiaineita voidaan yhdistää eheäksi kokonaisuudeksi. Oppitunnilla tehtävä työ on sellainen, johon voi helposti integroida muita oppiaineita mahdollisuuksiensa mukaan.

\section{Lähteet}

Czerniak, C. M. \& Johnson, C. C. (2014). Interdisciplinary science teaching. Teoksessa N. G. Lederman \& S. K. Abell (Toim.), Handbook of research on science education. (s. 395-410). New York: Routledge.

Fitzgerald, M. \& Tsosie, T. (2012). Cereal Box Design: An Interdisciplinary Graphics Activity. Tech Directions, 72, 27-34

Giddings, B., Hopwood, B. \& O’Brien, G. (2002). Environment, economy and society: fitting them together into sustainable development. Sust. Dev., 10, 187-196

Gilbert, J.K., Bulte, A.M.W. \& Pilot, A,. (2011). Concept Development and Transfer in Context-Based Science Education. International Journal of Science Education, 33(6), 817-837

Illeris, K., (2009). Transfer of learning in the learning society: How can the barriers between different learning spaces be surmounted, and how can the gap between learning inside the and outside the schools be bridged?, International Journal of Lifelong Education, 28(2), 137-148

Kangaskorte, A., Lavonen, J., Penttilä, A., Pikkarainen, O., Saari, H., Sirviö, J., Vakkilainen, K-M. \& Viiri, J., (2010). Kemia. Helsinki: WSOY Pro Oy, 1.-2. painos 
Kurt, K \& Pehlivan, M. (2013). Integrated programs for science and mathematics: Review of related literature. International Journal of Education in Mathematics, Science and Technology, 1(2), 116-121.

Miller, H. K. \& Jones, L. C. (2014). Analyzing sustainability themes in state science standards: Two case studies. Applied Environmental Education \& Communication, 13(3), 183-192.

OECD. PISA 2006 results. Internetistä http://www.oecd.org/fr/education/scolaire/programmeinternationalpourlesuividesacquisdeselevespi sa/pisa2006results.html. Luettu 27.4.2014.

Opetushallitus (2014). Perusopetuksen opetussuunnitelman perusteet 2014. Tampere: Juvenes Print - Suomen Yliopistopaino Oy

Warner, B. P. \& Elser, M. (2015). How do sustainable schools integrate sustainability education? An assessment of certified sustainable K-12 schools in the United States. The Journal of

Environmental Education, 46(1), 1-22.

\section{Onko veden käytöllä väliä? - kemian ja matematiikan eheyttävä oppitunti}

Nelly Heiskanen

\subsection{Johdanto}

Uusissa perusopetuksen opetussuunnitelman perusteissa (2014) nousevat entistä vahvemmin esille opetuksen arvoperustana kestävän elämäntavan välttämättömyys, oppimiskäsitys oppilaasta aktiivisena ja yhteiskuntaan osallistuvana toimijana, sekä tavoite oppilaan laaja-alaisesta osaamisesta. Uutena vaatimuksena on myös tarjota oppilaille ”vähintään yksi monialainen oppimiskokonaisuus lukuvuodessa"(Opetushallitus, 2014). Tässä artikkelissa esitellään tulevaisuuden opetuksen tarpeisiin kehitetty peruskoulun 7. luokan kemian ja matematiikan integroitu oppitunti aiheesta "onko veden kulutuksella väliä?” Tunnin suunnittelussa on käytetty apuna eheyttävän oppimisen ja työpistetyöskentelyn teorioita, sekä tutkimustietoa kestävän kehityksen opettamisesta. Oppitunti on pidetty Pohjois-Haagan yhteiskoulussa yhdelle ryhmälle 7. -luokkalaisia ja tuntisuunnitelmaan on tehty muutoksia kokeilun pohjalta.

Vesi ja sen ominaisuudet ovat yksi peruskoulun kemian keskeisistä sisällöistä (Opetushallitus, 2004). Peruskoulun opetussuunnitelman uudistuessa kemian opetuksen tavoitteet ja sisällöt ovat muuttuneet ja niissä painotetaan entistä enemmän eheyttävää ja arkilähtöistä opetusta, jossa oppilaita ohjataan kohti kestävän kehityksen mukaisia tavoitteita ja arvoja. Tarkastelemani yläkoulun kemian oppikirjat: Hehku (2012), Ilmiö (2010), Avain (2012) ja FyKe Kemia (2012) käsittelevät vettä aiheenaan lähinnä sen kemiallisten ominaisuuksien näkökulmista. Oppilaiden kasvattaminen kestävämpiin vedenkulutustapoihin ja vesiympäristöistä huolehtimiseen on mielestäni jäänyt kirjasarjasta riippuen hieman kemiallisten ilmiöiden varjoon. Opettaja voi kuitenkin valita sopivan opetusnäkökulman tilanteesta riippuen. Tämän artikkelin tarkoituksena on esitellä Kemian opetuksen keskeiset alueet II -kurssin puitteissa suunniteltu ja kokeiltu kemian ja 
matematiikan eheyttävä oppitunti, jossa pyritään huomioimaan paremmin uuden opetussuunnitelman tavoitteet eheyttämisen ja kestävän kehityksen kannalta.

\subsection{Vesi opetuksen kontekstina yläasteella}

Veden käyttö opetuksen kontekstina tarjoaa lukemattomia mahdollisuuksia peruskoulun kemian opetuksessa. Vedellä on monia ainutlaatuisia ja esimerkillisiä kemiallisia ominaisuuksia, kuten tiheyden muuttuminen eri olomuodoissa ja vetysidos. Kemian oppiainesisältöä painottava oppitunti vedestä keskittyy sen kemiallisiin ominaisuuksiin, mutta kestävän kehityksen arvojen opetteluun tähtäävä oppitunti käsittelee myös vettä luonnonvarana. Vesi luonnonvarana ja veden erilaiset käyttötarkoitukset kiinnostavat tasapuolisesti kaikenlaisia oppijoita (Tolvanen, 2011). Lisäksi sosioeettisistä ongelmista voidaan johtaa oppilaille merkityksellisiä kestävän kehityksen teemoja, kun käytetään vettä kontekstina opetuksessa (Eisen, Hall, Lee \& Zupko, 2009). Tutkimuskirjallisuudessa kuvattuja opetusteemoja ovat esimerkiksi vesi luonnonvarana, veteen liuenneet aineet (Cargill, 2000), globaalit vesiongelmat, veden saastuneisuus ja tapaus Afrikka - kuinka voimme puhdistaa vettä (Kosal, Lawrence \& Austin, 2010).

Aiheen tärkeys tulee esille myös uudessa opetussuunnitelmassa, jonka tavoitteena on "ohjata oppilasta käyttämään kemian osaamistaan kestävän tulevaisuuden rakentamisessa sekä arvioimaan omia valintojaan luonnonvarojen kestävän käytön ja tuotteen elinkaaren kannalta" (Opetushallitus, 2014). Tällaisia aiheita ovat esimerkiksi veden kuluttaminen, vesivarojen riittävyys, saasteongelmat, lähiympäristön vesistöjen tutkiminen, veden käyttö energianlähteenä ja vedenpuhdistus. Oppilaan tulisi ymmärtää puhtaan veden rajallisuus maailmassa (Pohjois-Haagan Yhteiskoulun opetussuunnitelma, 2005). Aihe on myös osana valtakunnallisen opetussuunnitelman perusteiden (2014) vastuu ympäristöstä, hyvinvoinnista ja kestävästä tulevaisuudesta -aihekokonaisuutta.

Uusissa perusopetuksen opetussuunnitelman perusteissa (2014) vesi kuuluu erityisesti kemian sisältöalueisiin S2 (Kemia omassa elämässä ja elinympäristössä), S3 (Kemia yhteiskunnassa) ja S5 (Aineiden ominaisuudet ja rakenne). Opetussuunnitelman perusteissa mainitaan veden ominaisuuksista happamuus ja veden liuotinominaisuudet (Opetushallitus, 2014), mutta sen tarkemmin ei aihetta ole rajattu tai vaadittu opetettavaksi. Peruskoulun kemian oppikirjoissa (Hehku, 2012; Ilmiö, 2010; Avain, 2012 ja FyKe Kemia, 2012) tarkasteltavia veden ominaisuuksia ovat muun muassa happamuus, emäksisyys, liuotinominaisuudet, poolisuus, suhteellisen korkea sulamis- ja kiehumispiste, kapillaariilmiö, pintajännitys, veden olomuodot, tiheys ja rakenne, sekä vetysidos. Lisäksi veden kiertokulku on mainittu useassa kirjassa. Ilmiö -kirjassa opetetaan myös veden ominaislämpökapasiteetti. Kestävän kehityksen teemaa on esitelty Avain -kirjan "Tiesitkö että..." -osiossa, jossa kerrotaan puhtaan veden kulutuksesta ja vedenpuhdistuksesta. Oppikirjoista eniten kestävän kehityksen teemaa käsitellään Hehku -kirjassa, jossa vettä tarkastellaan ensin veden kulutuksen ja ominaisuuksien kannalta ja sen jälkeen vesistöjen suojelun näkökulmasta. 
Aiempien tutkimusten, oppikirjoista saatujen esimerkkien ja uusien opetussuunnitelman perusteiden pohjalta oppituntini teemaksi valikoitui aihe "Onko veden käytöllä väliä?”. Oppitunnilla tutkitaan seuraavia veden ominaisuuksia kestävän kehityksen näkökulmasta: liukoisuus, rakenne, sulamis- ja kiehumispiste, olomuodot, kapillaari-ilmiö ja pintajännitys. Matematiikan eheyttäminen oppituntiin tuntui luonnolliselta valinnalta, koska matematiikalla on mielestäni edessään samat haasteet kuin kemian opetuksellakin; huomioida opetuksen arvoperustana kestävän elämäntavan välttämättömyys, omaksua oppimiskäsitys oppilaasta aktiivisena ja yhteiskuntaan osallistuvana toimijana, sekä pyrkimys oppilaan laaja-alaiseen osaamiseen. Mielestäni kestävän kehityksen teeman käsittelyn kautta voidaan mallintaa ongelmia matemaattisesti ja nähdä matematiikan ja reaalimaailman välisiä yhteyksiä. Nämä asiat ovat sekä vanhan että uuden opetussuunnitelman tavoitteita. Matematiikkaa onkin käytetty veden rajallisuuden kontekstissa ilmiön mallintamiseen (Cargill, 2000; Kosal et al., 2010).

\subsection{Onko veden käytöllä väliä? -oppitunnin teoreettinen pohja}

Oppitunnin suunnittelussa on otettu huomioon eheyttävän oppimisen ja työpistetyöskentelyn teoriat, sekä tutkimustietoa ja -kokeiluja kestävän kehityksen opettamisesta veden kontekstissa.

\subsubsection{Eheyttävä opetus}

Eheyttävän opetuksen on todettu lisäävän oppilaiden kiinnostusta ja motivaatiota opiskelua kohtaan (Gresnigt, Taconis, van Keulen, Gravemeijer \& Baartman, 2014; Samson, 2014). Eheyttävälle opetukselle tunnusomaista on oppilaslähtöisyys sekä oppilaille läheisten asioiden, kuten yhteiskunnallisten ongelmien käsittely sille kuuluvaa kokonaisvaltaista tietorakennetta käyttäen ilman tarkkoja ainerajoja. Eheyttävän opetuksen tutkittuja hyötyjä opetuksessa ovat muun muassa arkielämään liittyvien laaja-alaisten kokonaisuuksien hahmottaminen, syvemmän ymmärryksen saavuttaminen, ongelmanratkaisukykyjen kasvaminen, opiskelun merkitykselliseksi tekeminen oppilaille, sekä kiinnostuksen ja motivaation kasvattaminen. (Czerniak \& Johnson, 2014) Lisäksi uuteen opetussuunnitelmaan on tullut mukaan vaatimus yhden monialaisen oppimiskokonaisuuden järjestämisestä lukuvuoden aikana (Opetushallitus, 2014). On myös esitetty, että 2000-luvun työelämän taidot vaativat monitieteellistä ajattelua ja soveltamiskykyä (Eisen et al., 2009).

Matematiikan integroiminen kemian kanssa antaa oppilaille konkreettisen esimerkin matematiikan soveltamisesta oikeaan elämään ja auttaa oppilasta hahmottamaan aineen kemiallisia ominaisuuksia. Matematiikka ja kemia ovat vahvasti sidoksissa toisiinsa ja tukevat toisiaan opetuksessa. Tieteelliset ilmiöt motivoivat ja luovat merkityksiä matematiikan opiskeluun. (Czerniak \& Johnson, 2014). Matematiikan ja kemian integraatiota veden kontekstissa on käyttänyt esimerkiksi Cargill (2000) sekä Kosal, 
Lawrence ja Austin (2010). Cargill (2000) käytti matematiikkaa apunaan erilaisten pitoisuuksien ja prosenttiosuuksien hahmottamiseen. Kosalin, Lawrencen ja Austinin (2010) tutkimuskohteena olivat yliopisto-opiskelijoille suunnitellut biologian, kemian ja matematiikan eheyttävät kurssit, joiden teemana olivat aidot, globaalit vesiongelmat. Näiden tutkimusten pohjalta "Onko veden kulutuksella väliä?" -oppitunnille kehitettiin työpisteet "jäämiä vedessä" ja "puhdasta vettä".

\subsubsection{Kestävä kehitys opetuksessa}

Kestävällä kehityksellä on neljä ulottuvuutta; ekologinen, taloudellinen, sosiaalinen ja kulttuurillinen. Nämä yhdessä muodostavat kestävän kokonaisuuden, mitä ei saavuteta jos jokin ulottuvuuksista ei toteudu kestävästi. Esimerkiksi taloudellisen kestävyyden toteutuessa ympäristön kustannuksella puhutaan heikosta kestävyydestä. Tavoitteena on kuitenkin vahva kestävyys, jossa kaikki osa-alueet toteutuvat. (Heikkurinen, 2014). Tämän takia kestävään elämäntapaan ohjaamisessa tulisi huomioida kaikki ulottuvuudet asiaan kuuluvat näkökulmat huomioiden. Esimerkiksi veden rajallisuudesta puhuttaessa tulee huomioida vesivarojen maantieteellinen jakautuminen ja sen sosiaaliset vaikutukset. Tärkeimmät sosioeettiset ongelmat vaativat monitieteellistä yhteistyötä. (Eisen et al., 2009)

Vuoden 2014 perusopetuksen opetussuunnitelman perusteissa kemian opetuksen tehtävänä on "tukea oppilaiden valmiuksia tehdä valintoja sekä käyttää tietoja ja taitoja elämän eri tilanteissa”. Opetuksessa tulisi välittyä kemian merkitys kestävän tulevaisuuden mahdollistajana ja ohjata oppilaita huolehtimaan ympäristöstään. Kestävän kehityksen tavoitteet nousevat selkeästi esille myös opetuksen arvopohjassa, oppimiskäsityksessä ja tavoitteissa oppilaan laaja-alaisesta osaamisesta. Opetuksen tehtävänä on kasvattaa sivistykseen, johon kuuluu kestävien elintapojen välttämättömyys. (Opetushallitus, 2014) Kestävän kehityksen tavoitteiden painottuminen opetussuunnitelmassa on linjassa "Suomi, jonka haluamme 2050 - Kestävän kehityksen yhteiskuntasitoumuksen" kanssa (Ympäristöministeriö, 2013), mikä on myös perusopetuksen velvoite (Opetushallitus, 2014).

\subsubsection{Työpistetyöskentely opetuksessa}

Työpistetyöskentely on yhteistoiminnallinen työtapa, joka asettaa oppilaan aktiiviseen, omaaloitteiseen ja vastuulliseen asemaan. Sen hyötynä on vähälukuisten välineiden saaminen käyttöön jokaiselle oppilaalle. (Lavonen, Meisalo, \& et al. ) Onko veden kulutuksella väliä? tunnille työpistetyöskentely valikoitui siksi, että tietokoneita vesijalanjäljen mittaamiseen ja keittolevyjä lumen kuumentamiseen löytyi kemian luokasta vain yhdet kappaleet.

\subsection{Onko veden kulutuksella väliä? - oppitunti}

Oppitunnin idea veden kemian eheyttämisestä toiseen oppiaineeseen syntyi ajatuksesta motivoida oppilaita arjesta tutulla aiheella. Kestävä kehitys tarjosi mielestäni monitieteisen, mielekkään, arkilähtöisen ja tärkeän pohjan oppiaineita integroivalle tunnille. Oppitunnin tavoitteena oli auttaa oppilaita ymmärtämään puhtaan veden merkitys elämälle, vesiresurssien rajallisuus globaalilla tasolla sekä herättää oppilas ajattelemaan omien 
vedenkäyttötapojensa vaikutusta kestävän kehityksen näkökulmasta. Tavoitteena oli lisäksi veden ominaisuuksien tutkiminen ja matematiikan reaalimaailman yhteyksien näkeminen. Kemiaan integroitavaksi aineeksi valikoitui matematiikka molempien opettajien osaamisen ja aikaisempien opetuskokeilujen sekä löytyvän tutkimustiedon pohjalta.

Oppitunnin suunnittelussa pyrittiin huomioimaan veteen liittyviä virhekäsityksiä, joita liittyy esimerkiksi veden lämpötilan muuttumattomuuteen sulamis- ja kiehumispisteessä sekä veteen kiehuessa muodostuvien kaasukuplien sisältöön (Costu, 2008). Pohjois-Haagan yläasteella pidetty oppitunti koostui lyhyestä johdatuksesta aiheeseen, työpistetyöskentelystä sekä loppukoonnista. Johdatus aiheeseen sisälsi oppilaiden ennakkotietojen ja -kysymysten kartoituksen. Ennakkotiedot kerättiin oppilaiden taululle kokoaman vesiaiheisen miellekartan avulla. Sen jälkeen oppilaita pyydettiin kirjoittamaan lapulle, mitä he haluaisivat tietää vedestä. Miellekartan ja kysymysten lisäksi aiheeseen johdateltiin vielä diaesityksen avulla, jonka tarkoituksena oli herättää kiinnostus aiheeseen ja esittää veden rajallisuus maailmanlaajuisella tasolla karttakuvien avulla. On ensiarvoisen tärkeää ja oppilaslähtöisen opetuksen edellytys selvittää oppilaiden kiinnostusten kohteita etukäteen ja tämä on tärkeää myös eheyttävän opetuksen ja oppilaan motivoinnin kannalta (Czerniak \& Johnson, 2014).

Yhteensä kuudesta työpisteestä neljä käsitteli kestävää kehitystä. Yhdessä työpisteessä tuli miettiä vastauksia tunnin alussa esitettyihin ennakkokysymyksiin oppilaslähtöisesti. Muissa työpisteissä harjoiteltiin sekä kemiaan että matematiikkaan liittyviä taitoja tai käsitteitä. Esimerkiksi yhdessä työpisteessä käsiteltiin pintajännitystä ja kapillaari-ilmiötä sekä esiteltiin Fibonaccin lukujonoa. Oppitunti oli tarkoitus lopettaa yhteisellä työpisteiden teemojen käsittelyllä ja miellekartan parantelemisella työskentelyn pohjalta. Lopullista tuntirakennetta paranneltiin oppitunnilla havaittujen asioiden perusteella. Tarkempi kuvaus työpisteistä ja tuntisuunnitelmasta löytyy liitteestä.

\subsection{Yhteenveto}

Työpistetyöskentely tuki mielestäni eheyttävää opetusta hyvin oppilaskeskeisenä työtapana. Pidän itse siitä, että oppilaiden työskennellessä itsenäisemmin, opettajalla on mahdollisuus neuvoa ja ohjeistaa kutakin oppilasta yksilöllisesti vaikeissa asioissa. Tämä mahdollistaa paremmin myös oppilaiden tason huomioimisen ja oppilaan kohtaamisen yksilönä. Työpisteiden etuna on myös se, että ne pyrkivät tarjoamaan kaikille jotain mielenkiintoista. Kovin passiivisen ryhmän kanssa oma-aloitteinen ja oppilaslähtöinen työskentely saattaa tuottaa mielestäni aluksi hankaluuksia. Työpistetyöskentelyn voi kuitenkin valita soveltuvin osin tai käyttää sellaisenaan myös opettajajohtoisemmalla oppitunnilla.

Veden ominaisuuksien opiskelun voisi integroida myös muihin oppiaineisiin kuten esimerkiksi fysiikkaan, yhteiskuntaoppiin biologiaan tai maantietoon. Tällöin opiskeluun tulisi varata mielestäni paljon enemmän aikaa. Hyvä idea voisi olla esimerkiksi vesi luonnonvarana -teemapäivä. Teemapäivän aiheeksi vesi sopisi erityisen hyvin, koska me kaikki käytämme vettä päivittäin ja meillä kaikilla on vastuu puhtaan veden riittämisestä 
tulevaisuudessa. Tietoa kestävän kehityksen ja veden rajallisuuden vaikutuksesta ihmisiin voisi lisätä myös erilaisia artikkeleita käyttäen. Tästä oppitunnista jätin kuitenkin artikkelit pois, koska koin niiden vievän turhan paljon aikaa ryhmätöissä.

Toisaalta vesi on myös konteksti, jossa on paljon jo pelkästään kemiallisten ominaisuuksien tutkimiseen liittyviä aktiviteetteja kuten esimerkiksi tuntisuunnitelmasta pois karsiutunut jään tilavuuden kasvun kemia. Vesi tarjoaa myös muita mahdollisuuksia kestävän kehityksen opettamiseen esimerkkinä Itämeren tutkiminen tai veden käyttäminen energialähteenä. Lisäksi veden puhdistaminen olisi mielenkiintoinen sekä tärkeä osa-alue käsiteltäväksi.

Hankalinta tunnissa oli sen suunnitteleminen. Tunnilta jäi mietityttämään tilanne, miten kapillaari-ilmiön voisi sitoa kestävän kehityksen teemaan paremmin. Tällaista tilannetta kutsutaan eheyttämisen irrallisuuden ongelmaksi eli "sisältöesteeksi" (Czerniak \& Johnson, 2014). Kestävän kehityksen näkökulmien painottaminen opetuksessa vie mielestäni aikaa pois teoreettisimmilta asioilta, jolloin opettajan tulisi pohtia, mitkä ovat oikeasti tärkeimpiä asioita oppia. Kestävän kehityksen opettamiseen eheyttäminen sopii mielestäni loistavasti sen monitieteellisen luonteen ja oppilaslähtöisyyden takia. Lisäksi se auttaa vastaamaan perusopetuksen opetussuunnitelman tavoitteeseen eheän oppimiskokonaisuuden ja persoonan muodostumisesta, sekä kestävien elämäntapojen omaksumisesta.

\section{Lähteet}

Cargill, M. D. (2000). Water across the curriculum. Green Teacher, (63), 32-34. http://search.proquest.com.libproxy.helsinki.fi/docview/228738550?accountid=11365

Costu, B. (2008). Big bubbles in boiling liquids: Students' views. Chemistry Education Research and Practice, 9(3), 219-224. http://search.proquest.com/docview/742867673?accountid=11365

Czerniak, C. M., \& Johnson, C. C. (2014). Interdisciplinary science teaching. In N. G. Lederman, \& S. K. Abell (Eds.), Handbook of research on science education. (Volume 2 ed., pp. 365--411). New York: Routledge.

Eisen, A., Hall, A., Lee, T. S., \& Zupko, J. (2009). Teaching water: Connecting across disciplines and into daily life to address complex societal issues. College Teaching, 57(2), 99-104. http://search.proquest.com.libproxy.helsinki.fi/docview/61897963?accountid=11365

Gresnigt, R., Taconis, R., van Keulen, H., Gravemeijer, K., \& Baartman, L. (2014). Promoting science and technology in primary education: A review of integrated curricula. Studies in Science Education, 5O(1), 47-84. doi:10.1080/03057267.2013.877694

Happonen, J., Heinonen, M., Muilu, H., Nyrhinen, K. \& Saarinen, H. (2012). Avain. Kemia 1. Keuruu: Otavan Kirjapaino Oy.

Havonen, T., Karpin, T., Keinonen, T. \& Muurinen, M. (2012). Hehku. Kemia 7 - 9. Keuruu: Otavan Kirjapaino Oy

Heikkurinen, P. (2014). Kestävyyden käsitteen ulottuvuudet. Tieteessä Tapahtuu, 32(4).

Ikonen, M., Tuomisto, M., Termonen, M. \& Perkkalainen, P. (2010). Ilmiö. Slovenia: Kustannusosakeyhtiö Tammi.

Kangaskorte, A., Lavonen, J., Penttilä, A., Pikkarainen, O., Saari, H., Sirviö, J., Vakkilainen, K-M. \& Viiri, J., (2012). Kemia. Helsinki: Sanoma Pro Oy, 1.-4. painos 


\section{EHEYTTÄVÄÄ KEMIAN OPETUSTA OPPIAINEIDEN VÄLISENÄ YHTEISTYÖNÄ}

Kosal, E., Lawrence, C., \& Austin, R. (2010). Integrating biology, chemistry, and mathematics to evaluate global water problems. Journal of College Science Teaching, 4O(1), 41-47. http://search.proquest.com/docview/870288925?accountid=11365

Lavonen, J., Meisalo, V. \& et al. Matemaattis- luonnontieteellisten aineiden työtapaopas. http://www.edu.helsinki.fi/malu/kirjasto/yto/yto/

Opetushallitus (2004). Peruskoulun opetussuunnitelman perusteet 2004. Vammala: Vammalan kirjapaino

Opetushallitus (2014). Perusopetuksen opetussuunnitelman perusteet 2014. Tampere: Juvenes Print - Suomen Yliopistopaino Oy

Pohjois-Haagan yhteiskoulun johtokunta (2005). Pohjois-Haagan yhteiskoulun perusopetuksen luokkien 7-9 opetussuunnitelma. Internetistä

http://www.phyk.fi/portals/o/materiaalit/YlaasteenOps.pdf

Samson, G. (2014). From writing to doing: The challenges of implementing integration (and interdisciplinarity) in the teaching of mathematics, sciences, and technology. Canadian Journal of Science, Mathematics and Technology Education, 14(4), 346-358. doi:10.1080/14926156.2014.964883

Tolvanen, S. (2011). Veden kemian ja sen tutkimuksellisen opiskelun kiinnostavuus peruskoulussa (Pro gradu). Helsingin yliopisto.

Ympäristöministeriö (2013). Suomi, jonka haluamme 2050 - kestävän kehityksen yhteiskuntasitoumus. Internetistä http://www.ym.fi/fi-

FI/Ymparisto/Kestava_kehitys/Kestavan_kehityksen_yhteiskuntasitoumus

\section{Integrativ undervisning: Science and scientists Anna Sjöblom}

\subsection{Inledning}

I integrativ undervisning överskrider man ämnesgränserna i undervisningen. Det får undervisningssituationen att påminna mera om verkliga livet, ger djupare kunskaper àt eleverna och höjer deras intresse för fenomenet som lärs ut. Naturvetenskapens natur och konsten att planera en undervisning är en viktig del av högstadiets kemiundervisning. I den här artikeln presenteras en integrativ lektion i kemi och engelska får åk 8. Lektionen går ut på att eleverna lär sig om naturvetenskapernas natur med hjälp av Mythbusters, planerar en egen undersökning och presenterar den på engelska.

Största delen av vetenskapligt material är publicerat på engelska (SciFinder, 2015). Om man arbetar i en forskargrupp i Finland, går arbetet oftast på engelska. Därför är det naturligt att integrera ämnena kemi och engelska när man undervisar om naturvetenskapernas natur. Enligt den nya läroplanen kommer naturvetenskapernas natur att bli en viktig del inom kemiundervisningen (Opetushallitus, 2014).

Att komma på ett bra och intresseväckande sätt att undervisa om naturvetenskapernas natur är ett bra sätt att höja elevernas intresse för kemi. Tv-serien Mythbusters är ett beaktningsvärt alternativ att utnyttja i undervisningen om naturvetenskapernas natur och planerande av undersökningar. Serien framställer forskarna inom naturvetenskap på ett realistiskt sätt och lyckas fånga tittarnas intresse. (Zavrel, 2011) Lektionen jag planerade baserar sig på de här grunderna. 


\subsection{Teorier som stöder min lektion}

\subsubsection{Naturvetenskapernas natur}

Naturvetenskapernas natur går ut på att man inom naturvetenskaperna bara tror på det som går att bevisas. Inte på den mest populära forskaren som har publicerat flest artiklar, uppträtt i flest tv-program eller har flest följare på Twitter, utan på de teorier som bäst stämmer överens med vad som händer i verkligheten. Ny kunskap bygger på gammal kunskap, och man får reda på nya saker genom att tillämpa gammal kunskap på nya sätt. Därför är det viktigt att kunna kärnkunskapen inom naturvetenskapen för på basis av den kunna undersöka nya saker och tillverka ny och bättre teknik. Forskarteam samarbetar och delar med sig av sin kunskap. Naturvetenskapen är alltså en social vetenskap och kunskapen är universell. Verkligheten är oftast komplicerad, så forskare vill förenkla förhållandena så mycket som möjligt då de undersöker ett fenomen. De måste alltså bestämma vilken/vilka variabler de vill undersöka och skära bort allt onödigt från undersökningen. Målsättningen med naturvetenskapen är att undersöka världen som vi bor i och utveckla nya, bättre och mera underhållande produkter och metoder. Forskarna är alltså lite av dagens upptäcktsresande. (Ledermann \& Tobin, 2002; Zavrel, 2011) Naturvetenskapernas natur är en central del av den kommande läroplanen (Opetushallitus, 2014).

\subsubsection{Integrativ undervisning}

Med integrativ undervisning menar man att man överskrider ämnesgränserna i undervisningen. Det här kan ske genom att man antingen samtidigt undervisar flera ämnen under samma lektion eller genom att man parallellt undervisar samma fenomen inom flera olika ämnen. Typiskt för integrativ undervisning är att den behandlar ämnen och problem som är aktuella i samhället och/eller har kontext till elevernas vardag. (Czerniak \& Johnson, 2014; Gresnigt, Taconis, van Keulen, Gravemeijer \& Baartman, 2014).

Integrativ undervisning kommer att komma med i 2016 års läroplan för åk 7-9 (Opetushallitus, 2014). Jämfört med att bara undervisa alla ämnen skilt för sig utan att alls integrera dem har integrativ undervisning många fördelar. Integrativ undervisning påminner mera om verkliga världen än vad den traditionella indelningen av läroämnen som oftast bara artificiellt avgränsar undervisningsämnena från varandra gör. I arbetslivet är kunskaperna som behövs oftast integrativa med inlägg från många olika läroämnen. Målsättningen med integrativ undervisning är att den ska leda till kritiskt tänkande, erbjuda bättre möjligheter för problemlösning än den traditionella undervisningen samt ge den kärna av generell kunskap som behövs i framtiden. Med integrativ undervisning vill man skapa bredare koncept och djupare förståelse. Oftast gör integrativ undervisning också ämnet mera relevant, vilket ökar elevernas intresse och motivation. (Czerniak \& Johnson, 2014; Gresnigt et al., 2014)

Det krävs dock mera forskning kring integrativ undervisning. (Czerniak \& Johnson, 2014) Högstadiet ska erbjuda allmänbildning med ett brett kunnande (Opetushallitus, 2014). Integrativ undervisning är ett bra exempel på hur det här kan åstadkommas. Dessutom ska 
högstadiet erbjuda ekosocial bildning, d.v.s. lära ut en hållbar livsstil och möjliggöra en hälsosam uppväxt som leder till att eleverna fostras till bra samhällsmedborgare (Opetushallitus, 2014). För att uppnå det här målet krävs det parallell undervisning av samma fenomen inom många olika ämnen, d.v.s. integrativ undervisning. I undervisningen i högstadiet ska det ingå åtminstone en integrativ undervisningshelhet per år (Opetushallitus, 2014).

\subsubsection{Att höja intresset för naturvetenskaper med hjälp av demonstrationsvideor}

Intresse både stöder inlärningen och är en viktig målsättning för undervisningen. Intresserade elever lär sig bättre, och endas intresserade elever fortsätter med att studera naturvetenskaper efter grundskolan. Finländska högstadieelever är oroväckande ointresserade av naturvetenskaper. I PISA-undersökningen kom Finland på tredje sista plats när det gäller intresset för kemi. För att tillgodose behovet av framtida forskare är det relevant att höja det här intresset. (Olsen \& Lie, 2011; Lavonen, Byman, Uitto, Juuti, \& Meisalo, 2008)

Intresse relaterar till emotionell respons, vilket leder till uthållighet, som i sin tur leder till inlärning. Det finns tre olika sorters intresse: personligt intresse, situationsintresse och ämnesintresse. När det gäller att motivera de akademiskt omotiverade är det viktigt att först fånga ett situationsintresse. Det är också situationsintresset som är lättast för läraren att påverka. Utan att först skapa ett situationsintresse går det inte att arbeta vidare med att skapa ett personligt intresse. (Ainley, Hidi \& Berndorff,. 2002; Hidi \& Harackiewicz, 2000)

Väl utförda demonstrationer ökar elevernas intresse. De hjälper också läraren att växla lektionens tempo, vilket motverkar att eleven tappar intresset. För att lära sig måste eleverna aktivt engagera sig i demonstrationerna. De kan t.ex. förutspå resultaten, skriva ned vad de ser och diskutera demonstrationen. Eleverna kan komma ihåg resultat från lyckade demonstrationer i åratal. (Milner-Bolotin, Kotlicki \& Rieger, 2007; Crouch, Fagen, Callan \& Mazur, 2004)

Sedan 1957 har filmer använts i kemiundervisningen. För att filmen ska ha positiv effekt på inlärning och intresse måste man vid produktionen tänka på innehållet, den kemiska kunskapen, passande och effektiva bildval och längden på filmen. Filmer som en del av undervisningen har en positiv inverkan på elevernas motivation och drar effektivt till sig elevernas uppmärksamhet. (Pekdag \& Le Maréchal, 2010) Korta videosekvenser är effektivare än långa eftersom eleverna då koncentrerar sig bättre. För att höja intresset är det viktigt att videon kommunicerar med eleverna. Den måste ställa frågor, väcka diskussion och utmana tidigare uppfattningar. (Mitra, Lewin-Jones, Barrett \& Williamson, 2010)

\subsubsection{Att undervisa naturvetenskapernas natur med hjälp av Mythbusters}

Mythbusters är den kemirelaterade tv-serie som med god marginal har lyckats intressera många flera tittare än något annat kemirelaterat tv-program. Den har visats på Discovery 
Channel sen 2003, och en stor del av tittarna är tonåringar och unga vuxna (24 \% av besökarna på Mythbusters websida är i gymnasieåldern). Programmet bjuder på ett fönster till den vetenskapliga kulturen. Det går ut på att programledarna Adam Savage och Jamie Hyneman plus medhjälpare testar sanningen i myter, idiom och internetvideor med hjälp av tankebanor och processer som grundar sig på vetenskapliga metoder. (Zavrel, 2011)

Många högstadie- och gymnasieelever vet väldigt lite om vetenskap och teknik, och tycker bara att vetenskap är en sorts systematiskt upptäckande och teknik matematisk design. Därför är de inte heller särskilt intresserade av dessa. Mythbusters hjälper till att bota den här bristen på förståelse som unga människor har för vad vetenskap är genom att visa vetenskap på ett roligt, spännande och visuellt sätt. (Zavrel, 2011)

Mythbusters klargör skillnaden mellan vetenskap och teknik, d.v.s. vetenskap upptäcker och teknik/ingenjörskonst tillämpar vetenskapen för att göra livet säkrare, lättare eller mera underhållande, och visar hur vetenskapsmän litar på empiriska bevis istället för vad de hör andra säga. De försöker göra det de studerar enklare tvärtemot feluppfattningen att vetenskapsmän försöker få det de gör komplext, tillämpar etablerade principer på nya sätt, värderar säkerhet högt och konsulterar varandra och andra experter för råd. Programmet visar vetenskapsmän i ett realistiskt ljus istället för bara som stereotyper som skrämmer bort speciellt flickor. Om det visar sig för farligt med experiment som avslöjar all information låter de dem vara ogjorda. Dessutom är repliken "Testa inte det här hemma" ofta hörd i programmet. (Zavrel, 2011)

För att höja elevernas intresse för vetenskap måste de utsättas för en rik och nyanserad vetenskapskultur. Det kan anses vara oortodoxt att ta hjälp av en tv-serie, men bildande program har redan länge hjälpt till med att väcka intresse och utveckla förståelse för vetenskapen. (Zavrel, 2011)

Enligt läroplanen ska högstadieeleverna lära sig naturvetenskapens natur. De ska också lära sig att planera en undersökning. (Opetushallitus, 2004)

\subsection{Ett exempel på hur kan man undervisa naturvetenskapernas natur genom integrativ undervisning i kemi och engelska}

Jag höll en 75 min lektion i högstadiet Kungsvägens skola för en grupp på ca 20 elever i åk 8. Vi började lektionen med att tala om att "science" bara betyder naturvetenskap och inga andra vetenskaper och "scientist" bara betyder forskare inom naturvetenskap. Vi diskuterade varför engelska och naturvetenskaper går hand i hand. Efter det såg vi på ett par korta videoklipp av Mythbusters, där naturvetenskapliga experiment utfördes på engelska, och på basen av det gick vi igenom hur forskare arbetar och hur man planerar och utför en undersökning. Också det här gjordes delvis på engelska. Därefter fick eleverna i grupp planera en egen undersökning och presentera den på engelska för resten av gruppen. Då det ännu i slutet av lektionen fanns lite tid kvar såg vi på en Mythbusters-sekvens som hade anknytningar till en av elevgruppernas planerade undersökning. 
Lektionen kan räknas som integrativ undervisning eftersom den naturvetenskapliga forskningen presenterades på engelska precis som den presenteras i forskarnas arbetsliv. Eleverna fick planera forskningar angående ämnen som intresserade den, vilket också är typiskt för integrativ undervisning. Ämnesgränserna för kemi/naturvetenskaper och engelska överskreds.

Lektionen gick enligt den ursprungliga timplaneringen. Det enda som sattes till var den korta sekvens av Mythbusters som vi såg på i slutet av lektionen. Alla elever planerade ivrigt sina undersökningar trots att lektionen hölls sista timmen på fredag eftermiddag. När de planerade och presenterade sina undersökningar verkade de ha förstått både naturvetenskapernas natur och hur man planerar en undersökning. Både elever och lärare tyckte dessutom att det var roligt att se på Mythbusters. Att hålla lektionen med undervisningsämnena kemi och engelska integrerade gick bra. Kemiläraren hjälpte eleverna då det var fråga om kemirelaterade frågor och engelskaläraren då det handlade om språkrelaterade frågor. Att kemiläraren inte var så bra på engelska och engelskaläraren inte så bra på kemi störde inte lektionen. Istället kunde eleverna dra nytta av båda lärarnas sakkännedom.

Helheten kunde förbättras genom att hålla en extra lektion då eleverna kan utföra sina undersökningar. Eleverna önskade det här, och lärarna var överens om att det skulle vara en bra idé. Den extra lektionen kunde vara antingen integrerad eller bara kemi. Allt som allt var det här ändå en lyckad undervisningshelhet som lärarna kan rekommendera.

\subsection{Slutsatser och diskussion}

Eftersom integrativ undervisning kommer att bli en del av den kommande läroplanen (Opetushallitus, 2014) är det bra att komma på fungerande sätt att undervisa integrativt. Också undervisning av naturvetenskapernas natur hör till läroplanen (Opetushallitus, 2014). Med tanke på Finlands framtid är det viktigt att höja högstadieelevers intresse för naturvetenskaper (Olsen \& Lie, 2011; Lavonen et al., 2008). Att undervisa naturvetenskapernas natur med hjälp av Mythbusters är ett fungerande sätt att nå alla dessa tre mål (Zavrel, 2011).

Lektionen där jag undervisade naturvetenskapernas natur med hjälp av Mythbusters, med ämnena kemi och engelska integrerade, fungerade bra. Eleverna arbetade flitigt, använde både engelska och svenska, verkade intresserade av vad de gjorde och tycktes förstå naturvetenskapernas natur. Dock önskade eleverna en lektion till där de skulle ha haft tid att utföra sina undersökningar. Den här ena praktiska lektionen till skulle också passa bra ihop med läroplanens mål att ta med undersökande laborationer (tutkimuksellisuus) i undervisningen (Opetushallitus, 2014). 


\section{Källförteckning}

Ainley, M., Hidi, S., \& Berndorff, D. (2002). Interest, learning, and the psychological processes that mediate their relationship. Journal of educational psychology, 94(3), 545.

Czerniak, C. M. \& Johnson, C. C. (2014). Interdisciplinary science teaching. In N. G. Lederman \& S. K. Abell (Eds.), Handbook of research on science education. (s. 395-410). New York: Routledge.

Crouch, C., Fagen, A. P., Callan, J. P., \& Mazur, E. (2004) Classroom demonstrations: Learning tools or entertainment?. American Journal of Physics, 72(6), 835-838.

Gresnigt, R., Taconis, R., van Keulen, H., Gravemeijer, K., \& Baartman, L. (2014). Promoting science and technology in primary education: A review of integrated curricula. Studies in Science Education, 5o(1), 47-84. doi:10.1080/03057267.2013.877694

Hidi, S., \& Harackiewicz, J. M. (2000). Motivating the academically unmotivated: A critical issue for the $21^{\text {st }}$ century. Review of educational research, $70(2), 151-179$.

Lavonen, J., Byman, R., Uitto, A., Juuti, K., \& Meisalo, V. (2008). Students' interest and experiences in physics and chemistry related themes: Reflections based on a ROSE-survey in Finland. Themes in Science and Technology Education, 1(1), pp 7-36.

Lederman, N. G., \& Tobin, K. (2002). The nature of science. Dilemmas of Science Teaching: Perspectives on Problems of Practice, 7.

Milner-Bolotin, M., Kotlicki, A., \& Rieger, G. (2007). Can students learn from lecture demonstrations. $J$ Coll Sci Teach, 36, 45-49.

Mitra, B., Lewin-Jones, J., Barrett, H., \& Williamson, S. (2010). The use of video to enable deep learning. Research in Post-Compulsory Education, 15(4), 405-414.

Opetushallitus (2014), Perusopetuksen opetussuunnitelman perusteluonnos 2016, LUVUT 2-3 (s.719) http://www.oph.fi/download/160362_opsluonnos_perusopetus_vuosiluokat_7_9_19092014.pdf, luettu 15.04.2015.

Opetushallitus (2004). Perusopetuksen opetussuunnitelman perusteet 2004, LUKU 7.9 (s. 186-197) http://www.oph.fi/download/139848 pops web.pdf, luettu 15.04.2015

Olsen, R. V., \& Lie, S. (2011). Profiles of students' interest in science issues around the world: Analysis of data from PISA 2006. International Journal of Science Education, 33(1), 97-120.

Pekdag, B., \& Le Marechal, J. F. (2010). Movies in chemistry education. In Asia-Pacific Forum on Science Learning and Teaching (Vol. 11, No. 1, pp. 1-19). Hong Kong: Hong Kong Institute of Education.

SciFinder, https://scifinder-cas-org.libproxy.helsinki.fi/scifinder/view/scifinder/scifinderExplore.jsf, 31.05.2015

Zavrel, E. A. (2011). How the Discovery Channel Television Show Mythbusters Accuratrely Depicts Science and Engineering Culture. J Sci Educ Technol, 20, 201-207 